\title{
ANALISIS LAPORAN ARUS KAS UNTUK MENGUKUR KINERJA KEUANGAN PADA PT. PEGADAIAN (PERSERO)
}

\author{
Rahma Dona, Afriyeni \\ Akademi Keuangan dan Perbankan Padang \\ Afriyeni.yen@gmail.com
}

\begin{abstract}
ABSTRAK
Laporan arus kas merupakan alat yang digunakan untuk mengetahui seberapa besar kas yang telah digunakan untuk membiayai operasi perusahaan, apakah pengalokasian aliran kas masuk dan aliran kas keluar tepat dan efisien. Tujuan dari penelitian ini adalah untuk mengetahui bagaimana kinerja keuangan pada PT.Pegadaian(Persero) periode 2012-2014 dengan menggunakan rasio arus kas. Metode Penelitian ini adalah dengan menggunakan analisa data kuantitatif. Metode analisa data kuantitatif ini digunakan sebagai metode penelitian yang menjelaskan secara deskriptif mengenai analisis laporan arus kas untuk mengukur kinerja keuangan pada PT. Pegadaian (Persero). Hasil penelitian menunjukkan bahwa rasio arus kas operasi pada tahun 2012 menunjukkan angka yang negatif yaitu sebesar -0,0339 kali. Pada tahun 2013 dan 2014 menunjukkan angka yang positif. Rasio arus kas operasi terhadap bunga tahun 2013 lebih baik dibandingkan dengan rasio tahun 2012 dan 2014. Rasio pengeluaran modal untuk tahun 2013 dan 2014 mengalami penurunan dan menunjukkan angka yang negatif. Hal ini disebabkan karena kegiatan investasi (penerimaan kas) yang dilakukan tidak ada dan PT.Pegadaian(Persero) melakukan pembelian aset tetap (Pengeluaran kas).Nilai rasio total hutang untuk tahun 2013 lebih tinggi dibandingkan tahun 2012 dan 2014. Rasio arus kas operasi terhadap laba bersih tahun 2012 menunjukkan hasil yang negatif sedangkan tahun 2013 dan 2014 bernilai positif.
\end{abstract}

Kata Kunci: Laporan Arus Kas, Kinerja Keuangan

\section{LATAR BELAKANG}

Laporan keuangan merupakan data - data yang sifatnya kuantitatif. Laporan keuangan menggambarkan kondisi keuangan dan hasil usaha suatu perusahaan pada saat tertentu (Harahap, 2009:105). Jenis laporan keuangan yang lazim dikenal adalah neraca, laporan laba rugi, laporan perubahan ekuitas, laporan arus kas, laporan posisi keuangan.

Laporan arus kas sebagai bagian yang tidak dapat terpisahkan dari laporan keuangan perusahaan, yang menyajikan data mengenai kondisi kas perusahaan dan aktivitas operasi, investasi, dan pendanaan. Laporan arus kas memiliki kandungan informasi yang bermanfaat dalam menilai kinerja 
keuangan perusahaan yang bisa diperoleh melalui analisis laporan arus kas dengan menggunakan rasio arus kas.

PT. Pegadaian (Persero) merupakan salah satu perusahaan Badan Usaha Milik Negara (BUMN) yang bergerak di bidang jasa keuangan. Perusahaan ini mengelola jasa perkreditan berdasarkan hukum gadai. Penerimaan kas perusahaan ini diperoleh melalui beberapa produk jasa yang dijalankan oleh PT. Pegadaian (Persero) .

Pada PT. Pegadaian (Persero), kas merupakan elemen terpenting didalam perusahaan untuk menunjang kegiatan operasional.

Untuk mengetahui kinerja keuangan perusahaan maka informasi yang diperlukan adalah dari laporan arus kas PT. Pegadaian (Persero) periode 2012 sampai dengan 2014.

Tabel 1

PT.Pegadaian (Persero)

Laporan Arus Kas Periode 2012-2014 (dalam jutaan rupiah)

\begin{tabular}{|c|c|c|c|c|}
\hline \multirow[b]{2}{*}{ No } & \multirow[b]{2}{*}{ Uraian } & \multicolumn{3}{|c|}{ Tahun } \\
\hline & & 2012 & 2013 & 2014 \\
\hline 1 & Jumlah Kas Aktivitas Operasi & $\begin{array}{l}(598 \\
182)\end{array}$ & $\begin{array}{l}1.529 \\
682\end{array}$ & .382 \\
\hline 2 & Jumlah Kas Aktivitas Investasi & $\begin{array}{l}-114 \\
639\end{array}$ & $\begin{array}{l}-129 . \\
949\end{array}$ & 7-378.330 \\
\hline 3 & Jumlah Kas Aktivitas Pendanaan & $\begin{array}{l}900 . \\
864\end{array}$ & $\begin{array}{l}-1.598 . \\
828\end{array}$ & $\begin{array}{l}-426 . \\
469\end{array}$ \\
\hline
\end{tabular}

Sumber : PT. Pegadaian (Persero) Cabang Ulak Karang \& Data Diolah

Berdasarkan laporan arus kas selama 3 (tiga) periode menunjukan bahwa kinerja keuangan PT. Pegadaian (Persero) berada dalam kondisi yang tidak stabil. Untuk mengetahui kondisi kinerja keuangan PT. Pegadaian (Persero) perlu dilakukan perhitungan dengan rasio keuangan yang ada. Hal ini bertujuan agar manajemen dapat mengambil keputusan secara tepat terhadap keberlangsungan perusahaan.

Perumusan Masalah

Adapun perumusan masalah dalam penulisan tugas akhir ini yaitu bagaimana kinerja keuangan PT. Pegadaian (Persero) periode 2012-2014 dengan menggunakan rasio arus kas.

\section{TINJAUAN PUSTAKA}

\section{Laporan Keuangan}

Laporan keuangan merupakan gambaran mengenai posisi keuangan perusahaan selama periode waktu tertentu yang digunakan oleh pihak - pihak yang berkepentingan atas laporan keuangan tersebut.

\section{Bentuk - Bentuk Laporan Keuangan}

\section{Neraca}

Menurut Kasmir (2008:28) neraca (balance sheet) merupakan laporan yang menunjukkan posisi keuangan perusahaan pada tanggal tertentu. 


\section{Laporan Laba Rugi}

Menurut Kasmir (2008 :29) Laporan laba rugi (income statement) merupakan laporan keuangan yang menggambarkan hasil usaha perusahaan dalam suatu periode tertentu.

3. Laporan Perubahan Modal

Menurut Kasmir (2008:29) mengemukakan tentang laporan perubahan modal menyatakan bahwa Laporan perubahan modal merupakan laporan yang berisi jumlah dan jenis modal yang dimiliki pada saat ini.

4. Laporan Arus Kas

Menurut Kasmir (2008:29) mendefenisikan tentang laporan arus kas adalah laporan yang menunjukkan semua aspek yang berkaitan dengan kegiatan perusahaan, baik yang berpengaruh langsung atau yang tidak langsung terhadap kas.

5. Laporan Catatan Atas Laporan Keuangan

Menurut Kasmir (2008:30) mendefinisikan tentang laporan catatan atas laporan keuangan yaitu laporan yang memberikan informasi apabila ada laporan keuangan yang memerlukan penjelasan tertentu.

\section{Laporan Arus Kas}

Laporan arus kas yang disajikan sangat berguna bagi para pemakai laporan keuangan yaitu sebagai dasar untuk menilai kemampuan perusahaan dalam menggunakan arus kas tersebut.

\section{Klasifikasi Laporan Arus Kas}

1. Aktivitas Operasi

Jumlah arus kas yang berasal dari aktivitas operasi merupakan indikator menentukan apakah operasi entitas dapat menghasilkan arus kas yang cukup untuk melunasi pinjaman, memelihara kemampuan operasi entitas, membayar dividen, dan melakukan investasi baru tanpa mengandalkan sumber pendanaan dari luar.

2. Aktivitas Investasi

Aktivitas investasi adalah aktivitas perolehan atau pelepasan aktiva jangka panjang (aktiva tidak lancar) dan investasi yang tidak termasuk dalam pengertian setara kas.

3. Aktivitas Pendanaan

Aktivitas pendanaan adalah aktivitas yang mengakibatkan perubahan dalam jumlah dan komposisi kewajiban (hutang) jangka panjang dan modal (ekuitas) perusahaan. Aktivitas pendanaan berguna untuk memprediksi klaim atas arus kas masa depan oleh para penyedia modal entitas.

\section{Kinerja Keuangan}

Kinerja keuangan perusahaan merupakan suatu gambaran tentang kondisi keuangan suatu perusahaan yang di analisis dengan alat - alat analisis keuangan, sehingga dapat diketahui mengenai baik buruknya keadaan keuangan suatu perusahaan yang mencerminkan prestasi kerja dalam periode tertentu. 


\section{METODE PENELITIAN}

Di dalam melakukan penelitian ini akan digunakan metode - metode pengumpulan data, sebagai berikut :

\section{Metode Pengumpulan Data}

a. Studi Pustaka (Library Research)

Penelitian ini dilakukan dengan cara mempelajari buku - buku bacaan laporan - laporan dan publikasi yang berhubungan dengan objek penelitian.

b. Studi Lapangan (Field Research)

Penelitian ini dilakukan dengan menghubungi PT. Pegadaian (Persero) untuk memperoleh data yang diperlukan dan melakukan wawancara untuk mendapatkan data.

\section{Metode Analisa Data}

Dalam menganalisa data, penulis menggunakan metode analisa data kuantitatif. Metode analisa data kuantitatif ini digunakan sebagai metode penelitian yang menjelaskan secara deskriptif mengenai Analisis Laporan Arus Kas Untuk Mengukur Kinerja Keuangan Pada PT. Pegadaian (Persero).

\section{HASIL DAN PEMBAHASAN}

\section{Analisis Rasio Laporan Arus Kas pada PT.Pegadaian (Persero)}

1. Rasio Arus kas Operasi terhadap Kewajiban Lancar

Rasio ini menunjukkan kemampuan arus kas operasi perusahaan dalam melunasi kewajiban lancarnya. Rasio ini dihitung sebagai hasil bagi antara arus kas operasi dengan total kewajiban lancar.

$$
\text { Rasio AKO }=\frac{\text { Jumlah Arus Kas Operasi }}{\text { Kewajiban Lancar }}
$$

\section{Tabel 1}

Rasio Arus Kas Operasi Terhadap Kewajiban Lancar Periode 2012-2014 (Dalam jutaan rupiah)

\begin{tabular}{|c|c|c|c|c|}
\hline \multirow[b]{2}{*}{ No } & \multirow[b]{2}{*}{ Ket } & \multicolumn{3}{|c|}{ Tahun } \\
\hline & & 2012 & 2013 & 2014 \\
\hline 1 & Jumlah Arus Kas Operasi & & 1.529 & 793 \\
\hline & & 182 & .682 & .382 \\
\hline & & $\begin{array}{r}17 . \\
689 .\end{array}$ & $\begin{array}{r}17 . \\
689 .\end{array}$ & 18.009 \\
\hline 2 & Kewajiban Lancar & 388 & 388 & .251 \\
\hline 3 & Rasio Arus Kas Operasi & $-0,0339$ & 0,0868 & 0,0440 \\
\hline
\end{tabular}

Sumber:Data diolah, 2017 
Dari tabel diatas menunjukkan bahwa rasio arus kas operasi pada tahun 2012 menghaasilkan nilai yang negatif. Hal ini disebabkan oleh pengeluaran kas yang lebih besar daripada penerimaan kas.

Rasio arus kas operasi pada tahun 2013 dan 2014 menunjukkan angka yang positif yang artinya PT.Pegadaian (Persero) memiliki kemampuan yang lebih baik daripada tahun sebelumnya dalam memenuhi kewajiban lancarnya.

2. Rasio Arus Kas Operasi terhadap bunga

Rasio ini dihitung sebagai hasil bagi hasil antara arus kas operasi ditambah kas yang dibayarkan untuk bunga dan pajak dengan kas yang dibayarkan untuk bunga.

$$
\text { Rasio } A K O B=\frac{\text { Arus Kas Operasi }+ \text { Bunga }+ \text { Pajak }}{\text { Bunga }}
$$

Tabel 2

Rasio Arus Kas Operasi Terhadap Bunga

Periode 2012-2014 (dalam jutaan rupiah)

\begin{tabular}{|r|l|r|r|r|}
\hline \multirow{2}{*}{ No } & \multicolumn{1}{|c|}{ Uraian } & \multicolumn{3}{|c|}{ Tahun } \\
\cline { 3 - 5 } & \multirow{2}{*}{1} & $\mathbf{2 0 1 2}$ & $\mathbf{2 0 1 3}$ & $\mathbf{2 0 1 4}$ \\
\cline { 3 - 5 } & Jumlah & & & \\
& Kas Aktivitas Operasi & -598. & 1.529 & 793. \\
& & 182 & .682 & 382 \\
\hline \multirow{2}{*}{2} & Pembayaran Bunga & 2.072. & 2.174 & 2.183. \\
& & 564 & .955 & 099 \\
3 & Pajak & 672 & 655 & 600 \\
\hline & Rasio Bunga & .622 & .962 & .419 \\
\hline
\end{tabular}

Sumber : Data diolah, 2017

Dari hasil perhitungan diatas terlihat bahwa rasio arus kas operasi terhadap bunga tahun 2013 lebih baik jika dibandingkan dengan rasio tahun 2012 dan 2014. Rasio arus kas operasi terhadap bunga pada tahun 2013 yaitu sebesar 2,0049 kali menunjukkan bahwa PT.Pegadaian (Persero) mempunyai kemampuan yang lebih baik dalam menutup biaya bunga sehingga kemungkinan PT.Pegadaian (Persero) tidak mampu membayar bunga sangat kecil.

3. Rasio Arus Kas Operasi terhadap Pengeluaran Modal (PM)

Rasio ini digunakan untuk mengukur arus kas operasi yang tersediauntuk pengeluaran investasi. Rasio ini dihitung sebagai hasil bagi antara arus kas operasi dengan kas yang dibayarkan untuk pengeluaran modal, seperti pembelian aset tetap, akuisisi bisnis, dan aktivitas investasi lainnya.

$$
\text { Rasio PM }=\frac{\text { Aus Kas Operasi }}{\text { Pengeluaran Modal }}
$$


Tabel 3

Rasio Pengeluaran Modal

Periode 2012-2014 (dalam jutaan rupiah)

\begin{tabular}{|c|c|c|c|c|}
\hline \multirow[b]{2}{*}{ No } & \multirow[b]{2}{*}{ Keterangan } & \multicolumn{3}{|c|}{ Tahun } \\
\hline & & 2012 & 2013 & 2014 \\
\hline 1 & $\begin{array}{l}\text { Jumlah } \\
\text { Arus } \\
\text { Kas } \\
\text { Operasi }\end{array}$ & $\begin{array}{r}-598 . \\
182\end{array}$ & $\begin{array}{r}1.529 \\
.682\end{array}$ & $\begin{array}{r}793 \\
.382\end{array}$ \\
\hline 2 & $\begin{array}{l}\text { Pengeluaran } \\
\text { Modal }\end{array}$ & $\begin{array}{r}-114 . \\
661 \\
\end{array}$ & $\begin{array}{r}-129 . \\
949 \\
\end{array}$ & $\begin{array}{r}-378 . \\
330 \\
\end{array}$ \\
\hline 3 & $\begin{array}{l}\text { Rasio } \\
\text { Pengeluaran } \\
\text { Modal }\end{array}$ & 5,217 & $-11,78$ & $-2,097$ \\
\hline
\end{tabular}

Sumber: Data diolah,2017

Dari tabel diatas menunjukkan rasio pengeluaran modal untuk tahun 2012 adalah (Rp-598.182 : Rp114.661) sama dengan 5,217 kali. Rasio pengeluaran modal untuk tahun 2013 mengalami penurunan sebesar -11,78 kali. Rasio Pengeluaran modal untuk tahun 2014 yaitu sebesar Rp -2,097 kali yang menunjukkan kemampuan yang rendah dari arus kas operasi PT.Pegadaian (Persero) dalam membiayai pengeluaran modal (pembelian tambahan aset tetap).

3. Rasio Arus Kas Operasi terhadap Total Hutang

Rasio ini menunjukkan jangka waktu pembayaran hutang oleh perusahaan dengan asumsi semua arus kas operasi digunakan untuk membayar hutang. Dengan mengetahui rasio ini, kita bisa menganalisis dalam jangka waktu beberapa lama perusahaan akan mampu membayar hutang dengan menggunakan arus kas yang dihasilkan dari aktivitas operasional perusahaan.

$$
\text { Rasio Total Hutang }=\frac{\text { Arus Kas Operasi }}{\text { Total Hutang }}
$$

Tabel 4

Rasio Total Hutang

Periode 2012-2014 (dalam jutaan rupiah)

\begin{tabular}{|l|l|l|l|l|}
\hline & \multirow{2}{*}{ Keterangan } & \multicolumn{3}{|c|}{ Tahun } \\
\cline { 3 - 5 } No & \multicolumn{1}{|c|}{$\mathbf{2 0 1 2}$} & \multicolumn{2}{|c|}{$\mathbf{2 0 1 3}$} & \multicolumn{2}{|c|}{$\mathbf{2 0 1 4}$} \\
\hline 1 & Jumlah Arus Kas Operasi & -598.182 & 1.529 .682 & 793.382 \\
\hline 2 & Total Hutang & 22.142 .989 & 23.110 .734 & 24.136 .150 \\
\hline 3 & Rasio Total Hutan & $-0,0270$ & 0,0662 & 0,0329 \\
\hline 4 & \%Rasio total hutang & $2,7 \%$ & $6,62 \%$ & $3,29 \%$ \\
\hline
\end{tabular}

Sumber:Data diolah, 2017

Dari hasil perhitungan diatas terlihat bahwa nilai rasio total hutang untuk tahun 2012 adalah sebesar 2,7\% artinya PT.Pegadaian (Persero) mendapat 
modal untuk pembiayaan investasi dari kegiatan operasionalnya lebih rendah dari pengunaan dana untuk pembayaran hutang.

Nilai rasio total hutang untuk tahun 2013 adalah sebesar 6,62\% yang menunjukkan PT.Pegadaian (Persero) memiliki kemampuan yang tinggi untuk menutupi total hutang dari jumlah arus kas operasi dibandingkan tahun 2012. Sedangkan nilai rasio total hutang untuk tahun 2014 adalah sebesar 3,29\% yang berarti bahwa PT. Pegadaian(Persero) mengalami penurunan dalam membayar total hutangnya dari jumlah arus kas operasi.

5. Rasio Arus Kas Operasi terhadap Laba Bersih

Rasio arus kas operasi terhadap laba bersih menunjukkan seberapa jauh penyesuaian dan asumsi akuntansi akrual memengaruhi penghitungan laba bersih. Rasio ini dihitung sebagai hasil bagi antara arus kas operasi dengan laba bersih.

$$
\text { Rasio Laba Bersih }=\frac{\text { Arus Kas Operasi }}{\text { Laba Bersih }}
$$

Tabel 5

Rasio Arus Kas Terhadap Laba Bersih

\begin{tabular}{|c|c|c|c|c|}
\hline \multirow[b]{2}{*}{ No } & \multirow[b]{2}{*}{ Keterangan } & \multicolumn{3}{|c|}{ Tahun } \\
\hline & & 2012 & 2013 & 2014 \\
\hline 1 & $\begin{array}{l}\text { Jumlah } \\
\text { Arus } \\
\text { Kas Operasi }\end{array}$ & $\begin{array}{l}-598 \\
.182\end{array}$ & 1.529 .682 & 793.382 \\
\hline 2 & $\begin{array}{l}\text { Laba } \\
\text { Bersih }\end{array}$ & 1.904 .822 & 1.907 .303 & 1.708 .501 \\
\hline 3 & $\begin{array}{l}\text { Rasio } \\
\text { Laba } \\
\text { bersih } \\
\end{array}$ & $-0,3140$ & 0,8020 & 0,4643 \\
\hline 4 & Rasio laba bersih\% & $3,14 \%$ & $80,2 \%$ & $46,43 \%$ \\
\hline
\end{tabular}

Sumber :Data diolah,2017

Dari hasil perhitungan diatas terlihat bahwa nilai rasio laba bersih untuk tahun 2012 adalah sebesar -0,3140 yang berarti kemampuan laba setelah pajak dalam menutupi komitmen - komitmen yang akan jatuh adalah sebesar Rp -31,4\%. Sedangkan nilai rasio laba bersih untuk tahun 2013 adalah sebesar $80,2 \%$, semakin tinggi rasio ini menunjukkan bahwa kinerja keuangan perusahaan semakin baik, meskipun jumlah laba bersih yang kecil sebagai akibat besarnya beban non kas.

Pada tahun 2014 rasio laba bersih PT.Pegadaian (Persero) adalah sebesar $46,43 \%$ yang berarti mengalami penurunan dari tahun sebelumnya. Hal ini disebabkan oleh penurunan laba bersih yang diperoleh oleh PT.Pegadaian (Persero) yaitu laba sebelum pajak penghasilan sebesar Rp2.308.920 dan jumlah beban pajak sebesar Rp600.419 sehingga diperoleh hasil (Rp2.308.920Rp600.419) sama dengan Rp.1.708.501. 


\section{Analisis Rasio Laporan Arus Kas Sebagai Alat Ukur Kinerja}

Dalam penelitian ini menggunakan laporan arus kas selama 3 tahun yaitu tahun 2012 sampai dengan tahun 2014. Kinerja keuangan PT.Pegadaian (Persero) merupakan hasil dari berbagai aktivitas PT.Pegadaian (Persero) dengan memanfaatkan sumber daya yang ada pada PT.Pegadaian (Persero) .

Rasio Arus Kas Operasi pada tahun 2012 sampai 2014 menunjukkan pencapaian kurang dari 1, dengan demikian berarti PT.Pegadaian (Persero) tidak mampu melunasi kewajiban lancarnya hanya dengan menggunakan arus kas operasi saja.

Rasio arus kas operasi terhadap bunga tahun 2013 lebih baik jika dibandingkan dengan rasio tahun 2012 dan 2014. Rasio arus kas operasi terhadap bunga pada tahun 2013 yaitu sebesar 2,0049 kali menunjukkan bahwa PT.Pegadaian (Persero) mempunyai kemampuan yang lebih baik dalam menutup biaya bunga sehingga kemungkinan PT.Pegadaian (Persero) tidak mampu membayar bunga sangat kecil.

Tahun 2012 rasio pengeluaran modal PT.Pegadaian (Persero) menunjukkan angka rasio yang tinggi sehingga dimungkinkan pada tahun 2012 PT.Pegadaian (Persero) tidak akan mengalami kendala dalam membiayai pengeluaran modalnya melalui arus aktivitas operasi. Sedangkan pada tahun 2013 dan 2014 menunjukkan rasio yang bernilai negatif yaitu sebesar

11,78 kali dan 2,097 kali, hal ini disebabkan karena kegiatan investasi yang dilakukan PT.Pegadaian (Persero) adalah arus kas masuk sebesar Rp0 dan arus kas keluar (pembelian aset tetap) sebesar Rp129.949 sehingga net investasi keluar adalah sebesar (Rp0 - Rp129.949) sama dengan Rp-129.949. Pada tahun 2014 PT.Pegadaian (Persero) masih melakukan pembelian aset tetap sebesar Rp378.330 dan tidak melakukan penjualan aset tetap sehingga rasio pengeluaran modal bernilai negatif.

Dari perhitungan dengan rasio total hutang pada tahun 2012 PT.Pegadaian (Persero) menunjukkan angka -2,7\%. Selama kurun waktu 3 tahun PT.Pegadaian (Persero) pada tahun 2013 mengalami peningkatan dari tahun sebelumnya yaitu sebesar 6,62\% dan pada tahun 2014 memiliki angka rasio sebesar 3,29\% yaitu mengalami penurunan dari tahun sebelumnya. Hal ini menunjukkan kemungkinan PT.Pegadaian (Persero) mengalami kesulitan dalam membiayai pengeluaran modal melalui arus kas aktivitas operasi.

Rasio arus kas operasi terhadap laba bersih PT.Pegadaian (Persero) pada tahun 2012 meunjukkan hasil yang negatif. Hal ini disebabkan oleh jumlah arus kas operasi yang bernilai negatif yaitu sebesar Rp-578.182 dibagi dengan laba bersih Rp.1.904.822 sehingga diperoleh hasil 31,4\%. Untuk tahun 2013 dan 2014 diperoleh hasil 80,2\% dan 46,43\%. Hal ini menunjukkan kinerja keuangan PT.Pegadaian (Persero) cukup baik, hal ini dapat dilihat dari rasio laba bersih pada tahun 2012 yang bernilai negatif sedangkan tahun 2013 dan 2014 bernilai positif. 


\section{PENUTUP}

\section{Kesimpulan}

1. Rasio Arus Kas Operasi pada tahun 2012 menunjukkan angka yang negatif yaitu sebesar -0,0339 kali. Rasio arus kas operasi terhadap bunga tahun 2013 lebih baik jika dibandingkan dengan rasio tahun 2012 dan 2014. kecil.

2. Dari perhitungan rasio pengeluaran modal untuk tahun 2012 adalah sebesar 5,217 kali . Rasio pengeluaran modal untuk tahun 2013 mengalami penurunan dan menunjukkan angka yang negatif yaitu sebesar -11,78 kali. Rasio Pengeluaran modal untuk tahun 2014 yaitu sebesar -2,097 kali yang menunjukkan kemampuan yang rendah dari arus kas operasi PT.Pegadaian (Persero) dalam membiayai pengeluaran modal (pembelian tambahan aset tetap)..

3. Nilai rasio total hutang untuk tahun 2012 adalah sebesar $-2,7 \%$. Nilai rasio total hutang untuk tahun 2013 adalah sebesar 6,62\% yang menunjukkan PT.Pegadaian (Persero) memiliki kemampuan yang tinggi untuk menutupi total hutang dari jumlah arus kas operasi dibandingkan tahun 2012. Sedangkan nilai rasio total hutang untuk tahun 2014 adalah sebesar 3,29\%.

4. Rasio arus kas operasi terhadap laba bersih PT.Pegadaian (Persero) pada tahun 2012 menunjukkan hasil yang negatif. Untuk tahun 2013 dan 2014 diperoleh hasil 80,2\% dan 46,43\%. Hal ini menunjukkan kinerja keuangan PT.Pegadaian (Persero) cukup baik, hal ini dapat dilihat dari rasio laba bersih pada tahun 2012 yang bernilai negatif sedangkan tahun 2013 dan 2014 bernilai positif.

\section{Saran}

1. Laporan arus kas PT.Pegadaian (Persero) periode 2012 sampai 2014 berfluktuasi karena jumlah arus kas aktivitas operasi PT.Pegadaian (Persero) memiliki saldo negatif. Hal ini semestinya perlu diperhatikan oleh manajemen PT.Pegadaian (Persero) dan melakukan pengkajian hal - hal apa saja yang membuat saldo arus kas aktivitas operasi berfluktuasi dan penurunan saldo arus kas aktivitas operasi di tahun 2012.

2. Untuk menjaga kinerja keuangan PT.Pegadaian (Persero) hendaklah melakukan analisa terhadap pengeluaran modal (aset tetap) yang cenderung berfluktuasi. Hendaknya perusahaan meningkatkan jumlah arus kas operasi, sehingga jumlah arus kas operasi bisa membiayai pengeluaran modalnya.

\section{DAFTAR PUSTAKA}

Aprimardanus, 2013, Analisis Laporan Arus Kas Untuk Mengukur Kinerja Kuangan pada PT. Panin Insurance Tbk. Skripsi Sekolah Tinggi Ilmu Keuangan, Perbankan dan Pembangunan Padang.

Arifin, I. Z., \& Marlius, D. (2017). Analisis Kinerja Keuangan PT. Pegadaian Cabang Ulak Karang. https://doi.org/10.31227/osf.io/n2peu 
Fernos, J (2017). Analisis Rasio Profitabilitas Untuk Mengukur Kinerja (Studi Kasus Pada PT. Bank Pembangunan Daerah Provinsi Sumatera Barat. Jurnal Pundi. Vol 01. No 02. https://doi.org/10.31575/jp.v1i2.25

Harahap,Sofyan Syafri (2007), Analisis Kritis Atas Laporan Keuangan, PT. Raja Grafindo Persada, Jakarta

Hery, (2015), Analisis Laporan Keuangan,PT. Buku Seru, Yogyakarta

http://pegadaian.co.id

Ikatan Akuntansi Indonesia, (2009), Pernyataan Standar Akuntansi Keuangan.

Kasmir, (2008) menemukan pengertian Laporan Laba Rugi,Laporan arus kas,Catatan atas laporan keuangan dalam skripsi Aprimardanus 2013, Analisis Laporan arus kas untuk mengukur kinerja keuangan pada PT.PANIN INSURANCE Tbk,

Munawir,2004,Analisa Laporan Keuangan, Edisi Revisi, Penerbit Liberti, Yogyakarta

Rahmayeli, D. S., \& Marlius, D. (2017). Analisis Kinerja Keuangan Pada PT. Bank Perkreditan Rakyat (BPR) Batang Kapas Pesisir Selatan. https://doi.org/10.31227/osf.io/sz5db

Riyanto,Bambang.2001. Manajemen Keuangan. Yogyakarta :BPFE.

PSAK NO.2 (Revisi 2009): Laporan Arus Kas, IAIA, Jakarta

Shanjaya, A. R., \& Marlius, D. (2017). Peranan Laporan Keuangan Dalam Kebijaksanaan Pemberian Kredit Kepada Calon Nasabah Pada PT. BPR Batang Kapas. https://doi.org/10.31227/osf.io/uxmg6

Via, Pina, 2012, Analisis Laporan Arus Kas Untuk Mengukur Kinerja Keuangan Pada PT. Indofood Sukses Makmur, TBK, Skripsi Sekolah Tinggi Ilmu Ekonomi Keuangan, Perbankan dan Pengembangan Padang. 